\title{
STRATEGI PELAYANAN LINTAS BUDAYA BERDASARKAN MARKUS 4:1-34
}

\author{
Harming \& Katarina \\ Sekolah Tinggi Teologi Simpson \\ Jl. Agung No. 66, Krajan, Kel. Susukan, Kec. Ungaran Timur, Kab. Semarang, Jawa Tengah \\ Email: harmingsttsimpson@gmail.com
}

\begin{abstract}
Harming \& Katarina, Cross-cultural Service Strategy based on Mark 4: 1-34. The author conducted a study of the text of Mark 4: 1-34 using qualitative research literature study using the biblical hermeneutic principle. Based on the analysis of the text of Mark 4: 1-34 the authors find there are four cross-cultural service strategies namely by understanding local culture, using media.
\end{abstract}

Keywords: Cross Culture, Mark, Evangelism.

\begin{abstract}
Abstrak: Harming \& Katarina, Strategi Pelayanan Lintas budaya Berdasarkan Markus 4:1-34. Penulis melakukan penelitian terhadap teks Markus 4:1-34 dengan menggunakan penelitian kualitatif studi pustaka dengan menggunakan prinsip hermeneutik Alkitab. Berdasarkan analisis terhadap teks Markus 4:1-34 penulis menemukan ada empat strategi pelayanan lintas budaya yaitu dengan memahami budaya lokal, menggunakan media yang ada dalam budaya, memberdayakan potensi yang ada, dan menciptakan terobosan.
\end{abstract}

Kata kunci: Lintas Budaya, Markus, Penginjilan.

\section{PENDAHULUAN}

Memberitakan Injil merupakan tugas setiap orang percaya sebagaimana dituliskan dalam keempat Injil. Dekker (2002, p. 10) memaparkan bahwa "Perintah misi yang agung adalah kata pergi. Sebagaimana terdapat dalam Matius 28:18-20: "Pergi, jadikan murid, ajarlah..." Markus 16:15: "Pergi, beritakan kabar baik...." Lukas 24:47: "Pergi, beritakan pertobatan, pengampunan dosa...." Yohanes 20:21: "Seperti Bapa sudah mengutus Ku, Ku utus kau!" Namun Timo (2013, p. 24) menanggapi hal tersebut demikian "Yesus lahir ke dunia ini untuk membawa setiap agama dunia kepada pemenuhan-Nya. Maksudnya ialah seseorang yang bertemu Yesus melalui pengalamannya tidak perlu harus meninggalkan agamanya semula. Hal yang serupa ditambahkan oleh Hakh (2008, pp. 13-14) pandangan tentang kehidupan Yesus dan pemberitaan-Nya dalam Injil Sinoptik digambarkan secara berbeda-beda, tentu dipengaruhi dengan berbagai faktor seperti konteks budaya, sosial dimana Yesus melayani.
Terkait dengan penjelasan di atas, pemberitaan Injil merupakan sebuah tugas yang bersifat universal. Selanjutnya, Yewangoe (2009, p. 44) menjelaskan tentang universal artinya proses pemuridan itu bersifat luas, yang dimaksudkan disini ialah pemberitaan Injil bukan hanya bersifat verbal namun juga diperlihatkan melalui pelayanan diakonia yaitu menunjukkan kasih dalam hal menolong orang melalui kegiatan sosial.

Pelayanan diakonia tersebut semestinya bersifat lintas budaya (Cross culture) hal ini dimaksudkan karena orang-orang yang membutuhkan pelayanan tersebut memiliki kebudayaan yang berbeda. Terkait dengan pelayanan lintas budaya tersebut, Carson (2018, p. 2) memberikan sebuah pemahaman spesifik tentang budaya yaitu kumpulan nilai-nilai yang dimiliki secara luas oleh sebagian orang dari populasi manusia.

Pelayanan Lintas budaya merupakan sebuah kegiatan yang dilaksanakan dalam hal menolong orang lain di luar budaya sendiri. Definisi pelayanan dalam Kamus Besar Bahasa Indonesia yaitu berasal 
dari kata pelayan yaitu orang yang melayani, pelayanan ialah usaha yang dilakukan untuk melayani kebutuhan orang lain. Ensiklopedia Alkitab memberikan definisi tentang Pelayanan dalam bahasa $\mathrm{Yu}$ nani "leitourgos" artinya melayani, pelayan, pelayan Tuhan. Selanjutnya kata ini muncul dalam Filipi 1:1 "Dari Paulus dan Timotius, hamba-hamba Kristus Yesus, kepada semua orang kudus dalam Kristus di Filipi dengan para penilik jemaat dan diaken.” Kata "diaken, diakonos, diakonia" artinya pelayan, dan sering berupa pelayan di meja, hamba-hamba yang melayani. Pada masa Helenisme, istilah diakonos diberikan kepada orang yang bertanggung jawab atas keuangan, administrasi dan pelayanan yang begitu di hormati dalam Gereja mula-mula. Meskipun hal itu sering disebut pelayan, pelayanan, memberi bantuan, sumbangan. Secara rohani setiap pengikut Kristus disebut sebagai pelayan yaitu melaksanakan apa yang dikehendaki oleh Kristus. Pelayanan lintas budaya berarti sebuah usaha yang dilaksanakan dalam rangka menolong orang yang berada di luar budaya sendiri.

Injil Markus menjelaskan tentang pelayanan yang dilaksanakan oleh Yesus melintasi budaya orang Yahudi maupun non Yahudi, hal tersebut disampaikan dalam bentuk perumpamaan (Mrk. 4:134), dijelaskan juga dalam (Mat. 13:1-23) dan (Luk. 8:1-15). Menurut Hakh (2008, pp. 13-22) Injil Markus adalah Injil yang ditulis sebelum Injil Matius dan Lukas hal ini didasari beberapa argumentasi tentang teori-teori seperti Proto Markus yaitu suatu versi Markus yang lebih pendek; teori fragmen yaitu para rasul menulis kegiatan dan perkataan Yesus dalam bentuk kumpulan fragmen; teori ketergantungan yaitu tergantung pada sastra yang terdapat pada ketiga Injil Sinoptik.

Terkait dengan penelitian ini, Injil Markus merupakan bagian yang penuh dengan kegiatan dimana dalam Injil tersebut lebih menekankan apa yang di lakukan Tuhan Yesus daripada apa yang diajarkan-Nya. Hal tersebut terlihat dari beberapa $\mathrm{Mu}-$ jizat yang dikerjakan oleh Tuhan Yesus dan ada em- pat perumpamaan. Strategi pelayanan lintas budaya dalam Injil Markus ini, memiliki perbedaan dan keunikan dengan Injil lainnya. Hal tersebut dipengaruhi oleh latar belakang budaya para penulis. Misalnya, Matius menuliskan tentang pelayanan Yesus berdasarkan latar belakang Yahudi, hal itu terlihat dari ungkapan mengenai Kerajaan Allah dan kerajaan sorga. Kedua ungkapan tersebut memiliki makna sama, pemakaian kerajaan Sorga oleh Matius disebabkan latar belakang ke-Yahudi-an yang enggan memakai nama Allah (Carson, 2000:13). Selanjutnya, pelayanan lintas budaya dalam Injil Matius ini melalui penyembuhan terhadap penyakit dan pengajaran tentang nilai-nilai etis tentang kerajaan Allah (Mat. 5; 4:23; 9:35; 12:22-28).

Strategi Pelayanan Yesus dalam Injil Markus ini merupakan salah satu metode Pelayanan yang melintasi budaya dalam menyampaikan Injil kepada para pendengar. O 'dea (1996, p. 3) menjelaskan bahwa pelayanan lintas budaya sebagai pendekatan injil yang berusaha memahami sebuah budaya para diyakininya akan memiliki hasil untuk suatu kehidupan yang bermakna. Agama maupun kebudayaan sama-sama memiliki fungsi di dalam masyarakat dalam menjaga keseimbangan sosial. Dengan demikian, alasan tersebut di atas dapat dilihat melalui cara pendekatan yang dilakukan oleh Yesus kepada orang-orang dalam budaya yang berbeda.

Rumusan masalah penelitian ini adalah bagaimana strategi pelayanan lintas budaya berdasarkan Markus 4:1-34? Kemudian tujuan penulisan dari artikel ini adalah untuk menemukan strategi pelayanan lintas budaya berdasarkan markus 4:1-34.

\section{METODE}

Metode penelitian yang penulis pakai dalam penelitian ini adalah penelitian kualitatif dengan pendekatan studi pustaka (literatur study) yaitu metode Hermeneutik Alkitab. Metode hermeneutik Alkitab ialah sebuah upaya dalam menjelaskan, menerjemahkan, menganalisa serta menginterpretasi teks- 
teks yang terdapat pada Alkitab sehingga memudahkan para pembaca untuk memahami teks tersebut, Sutanto (2001, p. 10). Selain itu, Hermeneutik yang baik harus disertai dengan eksegesis yang benar sebab tanpa eksegesis yang baik maka hermeneutik akan menjadi subjektif (Nainggolan, 2013, p. 5). Menurut Sproul, untuk menghasilkan eksegesis teks Alkitab yang akurat serta memahami maksudnya, harus terlibat memunculkan pertanyaan terkait bahasa, gaya tulisan, sintaksis, konteks sejarah dan geografis, penulis dan bentuk sastra yang terdapat di dalamnya (Sproul, 2010, p. 124).

Dengan demikian, penulis menggunakan metode Hermeneutik Alkitab tersebut bertujuan untuk memberi pemahaman kepada para pembaca masa kini, agar mereka mengerti tentang berita yang dijelaskan dalam Alkitab yang memiliki kesenjangan waktu yang cukup lama. Adapun objek penelitian ini ialah Injil Markus.

Selanjutnya, sebagai Sumber utama yang digunakan dalam penelitian ini seperti (1) Alkitab Terjemahan Baru (TB);(2) Alkitab versi King James Version (KJV); (3) Alkitab versi Firman Allah Yang Hidup (FAYH); (4) Biblical Hebrew teks with vowel points (BHvp); (5) Interlinear Greek New Testament (IGNT), penelitian ini menggunakan aplikasi Sabda (OLB versi Indonesia) Versi 4.30 dalam memberikan penjelasan kepada beberapa hal berkaitan dengan Injil Markus. Kutipan ayat-ayat Alkitab dalam beberapa bahasa diambil dari aplikasi SABDA (OLB versi Indonesia) Versi 4.30. Kemudian ada beberapa sumber digunakan untuk mengkaji data berupa bahan-bahan interpretatif seperti, (1) Tafsiran-tafsiran Matthew Henry; (2) Tafsiran karya Warren W. Wiersbe; (3) Ensiklopedi Alkitab dan beberapa bahan lainnya; (4) Alkitab Edisi Studi; (5) Alkitab Penuntun Hidup Berkelimpahan; kemudian dalam penelitian ini, penulis juga menggunakan jurnal-jurnal yang mendukung penjelasan tentang penginjilan konteks budaya serta buku-buku berkaitan dengan metode Penginjilan lintas budaya.

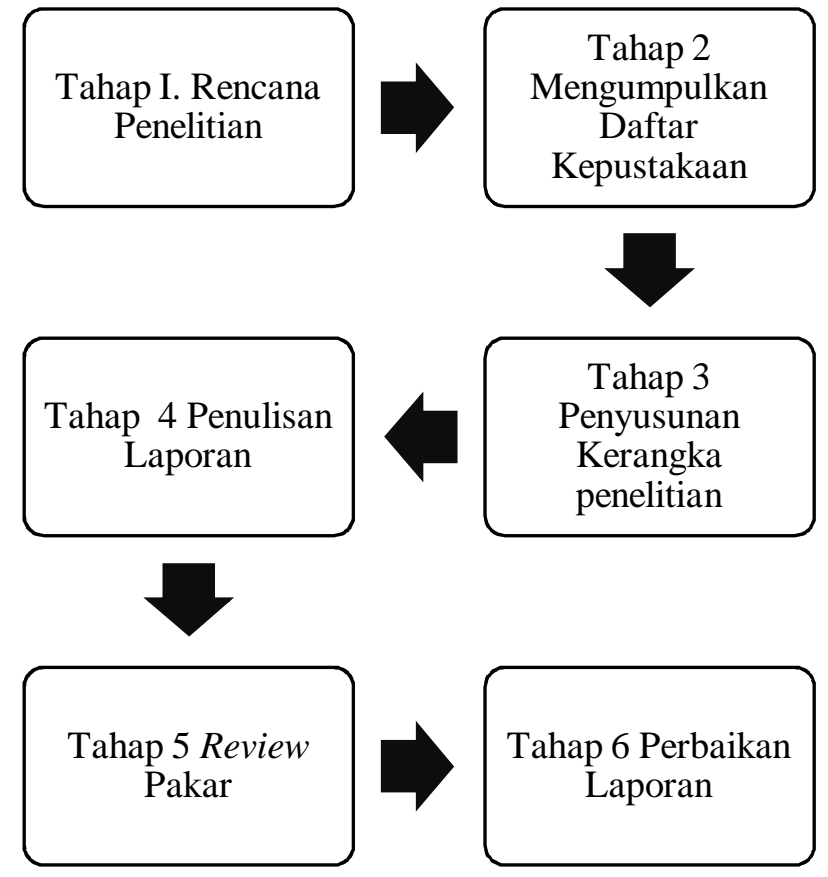

Gambar 1. Proses penelitian (Harming, 2017, p. 100)

\section{HASIL DAN PEMBAHASAN}

\section{Gambaran Markus 4:1-34}

Gambaran objek penelitian dapat dilihat dari latar belakang Injil Markus 4:1-34 dibandingkan dengan Matius 13:1-23 dan Lukas 8:4-15. Untuk mendapatkan kajian yang valid, termasuk teks atau yang yang menjadi sorotan penting, maka penulis meninjau dan membandingkan teks menggunakan lebih dari dua bahasa. Adapun teks yang dianalisis dari beberapa terjemahan, misalnya Markus 4:3: "Dengarlah! Adalah seorang penabur keluar untuk menabur...." (Terjemahan Baru), "Hearken; Behold, there went out a sower to sow...." (King James Version), "Dengarlah! Ada seorang petani yang akan menabur benih, ketika ia menabur benih itu diladangnya," (Firman Allah Yang Hidup). Selain terjemahan teks, gambaran objek penelitian akan ditinjau dari beberapa sisi seperti konteks budaya, konteks sosial, konteks spiritualitas orang Israel dari perspektif Markus. 


\section{Konteks Budaya}

Konteks budaya menurut Braga, kebudayaan berkenaan dengan ciri khas dari kelompok bangsa, agama atau sosial tertentu, dengan kata lain, kebudayaan berkaitan dengan apa yang dilakukan orang, gaya hidup, cara berpikir dan tindakan mereka sehingga terdapat sebuah kebiasaan bersama yang terdapat dalam masyarakat tersebut (Braga, 2005, p. 35). Kondisi budaya orang Israel, ketika Tuhan Yesus menyampaikan berita tentang kerajaan Allah, berada dalam sebuah situasi yang memiliki sistem ekonomi yang tradisional dimana hampir mayoritas penduduk sebagai nelayan dan petani. Selain itu budaya yang menonjol dalam masyarakat pada masa itu pada umumnya budaya lisan. Artinya, orangorang lebih mengandalkan komunikasi lisan dalam menyampaikan berita dan tidak banyak yang memiliki kemampuan untuk menulis kecuali hanya kelompok tertentu yang bekerja dilingkungan pemerintah di kota besar wilayah kekaisaran Romawi (Hakh, 2008, p. 5).

Injil Markus memulai tulisannya dengan proses Tuhan Yesus memulai pelayanan dengan memanggil murid-murid (Mrk. 1:14-20). Selanjutnya, di danau Galilea, Yesus bertemu dengan Simon, Andreas, Yakobus dan Yohanes.Mereka adalah para nelayan dan Yesus memanggil mereka untuk menjadi penjala manusia (Mrk. 1:21). Kemudian Yesus memanggil seorang pemungut cukai namanya Lewi (Mrk. 2:13-17). Hal ini menunjukkan bahwa murid Yesus juga dari berbagai kalangan yaitu orang-orang yang mendengar pengajaran Yesus (Mrk. 4:1). Walaupun demikian Yesus mengenal serta memahami keadaan para murid-Nya sehingga Ia dapat memenuhi kebutuhan mereka melalui pengajaran-Nya. Dari latarbelakang pekerjaan yang berbeda disatukan dalam sebuah misi yang Agung. Proses penyajian dalam Markus ini tidak saja memberi bayangan terhadap pelaksanaan misi tetapi juga memberi fondasi teologis untuk melibatkan orang yang belum percaya kedalam komunitas para murid. Yesus mengubah keadaan melalui orang di sekitar-Nya, sehingga ada pembaharuan di dalam diri para murid tidak hanya pekerjaan yang berubah, melainkan tujuan dan pandangan hidup. Injil Markus menceritakan latar belakang pemilihan para murid dengan lebih rinci dibandingkan Injil Matius, Lukas dan Yohanes.

\section{Konteks Sosial}

Secara umum, kondisi sosial masyarakat Yahudi pada masa Injil Sinoptik ini, terdapat para imam serta kelompok orang kaya menguasai baik perdagangan maupun pajak bahkan sampai di bait suci. Sementara kaum miskin dan rakyat biasa menjadi pertani, peternak, nelayan serta bekerja dibidang wiraswasta. Dalam penggolongan sosial, masyarakat terdiri atas kaum ningrat, kaum menengah, selanjutnya rakyat jelata, para budak dan penjahat. Secara keseluruhan, kondisi orang-orang Yunani serta bangsa lain yang berada di wilayah kekaisaran Romawi. Kondisi tersebut mewarnai kehidupan sosial ketika Markus menulis Injil ini. Adapun lingkungan yang digunakan disini ialah tepi Danau Galilea (http: //pesta.sabda.org/ppb_pel01). Hal itu terjadi pada saat Yesus berkeliling di Galilea, orang banyak berkerumun mengikuti serta meminta-Nya untuk berbicara kepada mereka dari sebuah perahu yang terapung tidak jauh dari tepi danau (Tafsiran Alkitab Wycliffe, Yayasan Lembaga SABDA, Versi 4.30, 6 September 2013). Drane (2001, pp. 209-210) mengungkapkan bahwa Injil Markus ini ditulis kepada para pembaca non Yahudi, ungkapan dalam Bahasa Aram seperti 'Talitakum, Effata' (Mrk. 5:41; 7:34) hal tersebut diterjemahkan dalam bahasa Yunani supaya pembaca lainnya mengerti. Selain itu, ada dugaan bahwa kondisi sosial masa itu berada pada masa pemerintahan Nero yang memfitnah orang Kristen dengan menuduh mereka membakar kota Roma, sehingga situasi itu merupakan situasi yang mencekam bagi orang Kristen dan terancam oleh penganiayaan (Drane 2001, pp. 209-210). Sedangkan Injil Sinoptik lainnya, seperti Matius, Lukas dan Yohanes memberikan pemaparan tentang konteks sosial berpusat kepada kehidupan di istana. 
Situasi sosial dalam Injil Markus adalah sebuah keadaan yang memiliki kompleksitas sehingga persoalan yang terjadi pun begitu kompleks. Hal tersebut juga berpengaruh kepada orang-orang yang mengikuti Yesus ingin melihat mujizat dan kesembuhan terjadi.

\section{Konteks Agama}

Berdasarkan tradisi yang ada, orang Yahudi menganut kepercayaan dan beragama Yudaisme pada tahun 70 sampai 100 Masehi. Sedangkan Injil Markus diperkirakan di tulis pada masa itu, dengan demikian situasi orang percaya berada di tengah-tengah kepercayaan lokal yang berkembang pada waktu itu. Markus sendiri diperkirakan sudah menjadi orang percaya yang tinggal di Yerusalem (Yayasan Lembaga SABDA Versi 4.30, 6 September 2013). Berdasarkan situasi ini, besar kemungkinan orang percaya berada dalam kondisi yang tidak tentram. Injil Markus menuliskan tentang Yesus yang menjadi manusia secara khusus sebagai seorang hamba. Iman Kristen yang diajarkan oleh Yesus dalam Injil Markus ini berbeda dengan iman yang ada pada masa itu, selain itu Markus ingin memberikan kekuatan dan penghiburan bagi orang percaya yang berada ditengah situasi yang tidak baik. Injil Markus ditulis untuk orang Romawi dan Injil Lukas untuk Teofilus dan semua orang percaya bukan Yahudi, maka Injil Matius ditulis untuk orang percaya bangsa Yahudi.

\section{Strategi Pelayanan Lintas Budaya}

Dalam pasal 4 dari Injil Markus, Yesus mengajarkan tentang Kerajaan Allah dengan menggunakan strategi perumpamaan atau ilustrasi. Injil Markus membuktikan bahwa Yesus bertindak, melayani, mengorbankan diri, dan menyelamatkan, sehingga pembaca yang membaca Injil Markus mendapat gambaran untuk bertindak, terbuka terhadap gerakan Allah di dalam kehidupan dan berani menerima tantangan untuk melayani di lingkungan. Dalam pelayanan-Nya, Yesus melintasi berbagai hambatan kebangsaan, ras, ekonomi, dan budaya untuk menyebarkan Injil-Nya. Pesan dari pelayanan yang Yesus lakukan ialah iman dan pengampunan bagi seluruh suku bangsa. Meskipun dalam kitab Injil sebelumnya, Yesus menggunakan strategi ini, namun dalam pasal ini Dia mempergunakan strategi tersebut sebagai sarana memberitakan Injil kerajaan Allah. Dalam menceritakan tentang kerajaan Allah tersebut, Yesus menggunakan strategi bercerita memakai perum-pamaan atau ilustrasi dengan tujuan agar semua lapisan masyarakat dapat mengerti. Adapun strategi-strategi tersebut yaitu:

\section{Memahami Budaya Lokal}

Yesus mengajar orang-orang dengan perumpamaan dan ilustrasi, menggunakan kejadian-kejadian yang lazim untuk menjelaskan kebenaran-kebenaran rohani. Metode mengajar Yesus mendorong pendengar untuk berpikir dengan apa yang sedang terjadi dalam kehidupan mereka. Perumpamaan atau ilustrasi tentang seorang penabur diceritakan dengan jelas oleh Markus, bagaimana Yesus mengisahkan tentang seorang penabur yang sedang menabur benih pada tanah yang berbeda-beda. Yesus menggunakan ilustrasi ini kepada masyarakat di sekitar Daerah Galilea yang memiliki ciri khas petani, akan sangat menolong mereka untuk memahami secara mudah isi berita tersebut. Isi berita akan tersampaikan dengan baik apabila, sang pembawa berita dapat masuk ke dalam budaya lokal dan menyelaraskan isi berita dengan budaya yang ada tanpa mengurangi makna dari berita tersebut. Dalam Injil Markus Yesus menekankan tentang Injil Kerajaan Allah, yang diberitakan dan respon setiap orang yang mendengarkan berita tersebut. Para pengikut-Nya dan kedua belas murid memiliki rasa penasaran, sehingga ada pertanyaanpertanyaan yang diajukan kepada Yesus. Dalam penjelasan-Nya Yesus masuk dalam budaya lokal dan menjelaskan sesuai dengan budaya setempat. Dengan menggunakan perumpamaan tentang seorang penabur dan penjelasan mengenai penabur yang menabur benih pada beberapa jenis tanah, dapat dilihat pada ayat 14-20. Konteks berita tersebut disampai- 
kan ialah kepada orang-orang sekitar Galilea, namun bukan hanya kepada masyarakat yang belum mengerti maksud perumpamaan tersebut, tetapi para murid pun masih belum memahami akan isi dari ilustrasi yang di ajarkan oleh Yesus, sehingga mereka bertanya secara pribadi kepada Yesus. Henry (Tafsiran Matthew Henry, Yayasan Lembaga SABDA Versi 1.4.1, Mei 2018) menjelaskan bahwa tidak ada buah yang baik dapat diharapkan selain dari bibit yang baik. Selanjutnya, bila benih ditabur di atas tanah yang subur, yaitu ketika orang tersebut rendah hati, kudus serta rohani maka akan nampak buah yang baik.

Kebutuhan manusia akan kebenaran Allah terkadang disampaikan hanya sebagai produk agama saja. Pemahaman tentang Alkitab telah memunculkan polemik, salah satu yang disoroti ialah benarkah Yesus adalah Allah? Benarkah hanya di dalam Yesus ada Keselamatan? Jawaban tersebut perlu mendapatkan jawaban yang serius (Samarenna, 2017, p. 20). Hal tersebut seringkali menjadi persoalan primer bagi manusia tatkala bersentuhan dengan pemberitaan Injil.

Pelayanan lintas budaya terimplisit dalam Injil Markus melalui sebuah ilustrasi atau perumpamaan tentang seorang penabur. Perumpamaan tentang seorang penabur adalah salah satu perumpamaan yang dijelaskan oleh Yesus kepada muridmurid-Nya dan pengikut-pengikut-Nya, tidak disangka melalui perumpamaan ini mengundang perhatian dari para murid dan pengikut-pengikut-Nya sehingga Yesus kembali menjelaskan secara rinci dalam Injil Markus ayat 14-20. Yesus memahami apa yang menjadi kebutuhan para murid dan pengikut-pengikut-Nya, sehingga apa yang diungkapkan-Nya selalu dinantikan, tidak jarang pernyataan Yesus mengundang tanya dari para murid dan pengikut-pengikut-Nya, sehingga ada interaksi yang terjadi (Mrk. 4:10) yang menabur bibit di beberapa jenis tanah memberi gambaran kepada manusia tentang kondisi tiap orang yang berbeda-beda, ilustrasi tanah (Mrk. 4:15-20) tanah di pinggir jalan, tanah bercampur batu, tanah di semak duri, dan tanah yang subur yaitu mengenai hati manusia. Hal tersebut membutuhkan suatu strategi sehingga sedapat mungkin pemberitaan Injil tersebut dapat dipahami oleh setiap pribadi yang ada. Menurut Siswanto (2017, p. 66) pemberitaan Injil yang kontekstual perlu adanya sikap yang bijak, menghargai budaya tanpa adanya sinkristme. Dengan demikian, pemberitaan Injil yang benar semestinya memperhatikan objek pemberitaan sehingga maksud berita dapat disampaikan dengan baik.

\section{Menggunakan Media Yang Ada Dalam Budaya}

Pada bagian ini, Yesus menyampaikan suatu cerita yang tidak asing bagi masyarakat umum yaitu tentang pelita atau lampu. Markus memulai cerita ini dengan ungkapan Tuhan Yesus: "apabila seseorang memasang pelita, apakah ia akan menutupinya dengan sebuah kotak untuk menghalanginya? Tentu saja tidak! Sebab kalau tertutup, cahayanya tidak akan terlihat..." (Mrk. 4:21 FAYH). Wycliffe menjelaskan, tujuan Yesus pada bagian ini adalah memberikan penekanan akan tanggung jawab yang diwajibkan kepada pendengar bahwa apabila hatinya telah dicerahkan oleh firman, pada saatnya harus menyampaikan hal itu kepada orang lain (Tafsiran Wycliffe, Yayasan Lembaga SABDA Versi 1.2.0, 2016). Pada bagian ini, Tuhan Yesus sedang mengantisipasi adanya eksklusifisme yang dapat terjadi dalam kehidupan iman mereka. Markus 3:7-10 merupakan fakta yang menyatakan bahwa Yesus melakukan misi penginjilan bukan hanya kepada orang yang ada di sekitar Galilea atau kepada bangsa sendiri, tetapi sampai ke daerah yang di sebut Kafir.

Menyampaikan Injil kepada semua orang berarti terjadi sebuah komunikasi lintas budaya dimana antara si pemberita dengan penerima berita terdapat budaya yang berbeda. Tantangan yang seringkali terjadi apabila terjadi komunikasi lintas budaya adalah kesalah pahaman karena keduanya belum saling mengenal. Menghadapi tantangan tersebut, Markus memberikan contoh strategi yang rele- 
van pada bagian ini melalui ilustrasi yang dapat dimengerti oleh semua kalangan. Secara umum masyarakat senang mendengarkan cerita, apalagi yang berkaitan dengan kebudayaan yang ada di masyarakat tersebut. Riniwati (2016) menjelaskan bahwa seorang Kristen harus merefleksikan iman Kristen ke dalam pergaulan lintas agama bukan hanya kepada sesama iman saja. Kesaksian orang percaya melalui pergaulan kepada semua orang dengan disertai tindakan yang bermakna, bukan hanya sebatas ungkapan kata-kata.

\section{Memberdayakan Potensi yang Ada}

Ilustrasi tentang benih ini terdapat dalam Injil yang lain, misalnya Matius 13:1-23. Perumpamaan tentang benih masih berkaitan dengan tentang penabur pada beberapa jenis tanah (Mrk. 4:1-20) perbedaannya ada pada penekanan ilustrasi tersebut, jika penabur menekankan pada tanah sedangkan tentang benih ini lebih kepada proses pertumbuhan sehingga mencapai hasil yaitu buah. Dalam konteks ini, para pengikut ditugaskan untuk menerima Injil bukan hanya untuk diri sendiri melainkan juga untuk orang lain. Selanjutnya orang percaya juga diperintahkan untuk mempraktikkan kebaikan kepada semua orang sebagai bukti nyata dari penerimaannya terhadap kasih karunia Allah.

Yesus menyampaikan tentang benih yang ditabur dan tanpa campur tangan manusia benih itu bertumbuh dengan sendirinya, hal ini menjelaskan tentang kedaulatan Allah dalam segala kehidupan di dunia ini. Demikian juga hal dengan keselamatan, tugas orang percaya menyampaikan Injil serta mendoakan sesama manusia, namun perkara menyelamatkan adalah bagian Roh Kudus. Packer (2014, p. 6) berkata: orang Kristen paling waras dan bijaksana pada saat berdoa, anda tahu bahwa Allah yang menyelamatkan manusia; anda tahu manusia datang kepada Allah hanya karena Anugerah-Nya yang membawa mereka datang kepada-Nya.

Pemberitaan Injil pada setiap tempat, tentu memiliki berbagai karakteristik kebudayaan masing- masing. Hal tersebut sudah pasti membutuhkan strategi yang relevan. Pendekatan Yesus kepada masyarakat yang ada di sekitar danau Galilea yaitu menggunakan ilustrasi tentang benih, dan hampir semua mengerti tentang hal itu, merupakan suatu pendekatan lintas budaya. Strategi pendekatan lintas budaya memiliki beberapa indikator sebagai berikut diantaranya: kebudayaan masyarakat yang ada di daerah Galilea berbagai macam dan kebudayaan Yesus pun berbeda dengan mereka.

\section{Menciptakan Terobosan}

Strategi penginjilan lintas budaya selanjutnya ialah ilustrasi tentang biji sesawi. Injil Markus memberikan perumpamaan ini menggambarkan tentang progres pertumbuhan dan kemajuan yang pesat dari Kerajaan Allah yang terlihat dari luar. Gambaran tentang biji sesawi yang kecil bahkan menurut Markus 4:31 adalah biji yang terkecil di antara biji sayuran lainnya. Namun apabila biji tersebut tumbuh ia menjadi lebih besar dari sayuran yang lain, sehingga burung dapat membuat sarang di rantingnya.

Menciptakan terobosan dalam pelayanan lintas budaya sangatlah penting sebagai tolak ukur dan penerapan dari strategi pelayanan. Yesus memberikan sebuah pemahaman dan pengertian dalam ilustrasi-ilustrasinya tentang seorang penabur; ilustrasi tentang pelita; ilustrasi tentang benih dan; ilustrasi tentang biji sesawi. Dalam setiap ilustrasi ada nilai-nilai kebenaran di dalamnya yang hendak Yesus sampaikan tanpa mengurangi makna dari media yang digunakan.

Penggunaan strategi ini dianggap relevan dalam menyampaikan Injil dalam lintas budaya karena cerita yang digunakan adalah informasi yang dikenal oleh semua kalangan sosial. Memakai ilustrasi yang diketahui secara umum akan memudahkan para pendengar untuk menanggap pemberitaan yang disampaikan. Dalam konteks Injil Markus ini, ilustrasi tentang biji sesawi merupakan sebuah pengalaman langsung orang-orang yang berada di daerah Galilea. Hal yang serupa dijelaskan Wijaya 
dan Darmawan (2016, pp. 53-55) bahwa pendekatan penginjilan yang diajarkan dalam konteks Bali merupakan pendekatan lintas budaya yang dapat digunakan antara lain ialah pendekatan argumentatif positif, pendekatan kasih Kristus, pendekatan pola pikir yang relevan, pendekatan pribumi nilai Kristen, pendekatan pada konsep-konsep yang serupa serta pendekatan jaringan keluarga. Strategi bercerita dengan ilustrasi benih sesawi dalam konteks Yahudi serta pendekatan yang dilakukan dalam konteks budaya Bali merupakan strategi yang berbasis lintas budaya.

\section{KESIMPULAN}

Dari analisis terhadap pasal 4 dari Injil Markus, tampak jika Yesus mengajarkan tentang Kerajaan Allah dengan menggunakan strategi perumpamaan atau ilustrasi. Pelayanan Yesus digambarkan dalam Injil Markus sebagai pelayanan yang melintasi berbagai hambatan kebangsaan, ras, ekonomi, dan budaya untuk menyebarkan Injil-Nya. Hasil analisis terhadap Markus 4 tampak ada empat strategi pelayanan lintas budaya yang Yesus gunakan. Strategi pertama adalah memahami budaya lokal. Perumpamaan tentang penabur yang digunakan Yesus terkait dengan budaya lokal di mana masyarakat di sekitar Daerah Galilea yang memiliki ciri khas petani, pendekatan-Nya akan sangat menolong para pendengar-Nya untuk memahami secara mudah isi berita tersebut. Isi berita akan tersampaikan dengan apabila, sang pembawa berita dapat masuk kedalam budaya lokal dan menyelaraskan isi berita dengan budaya yang ada tanpa mengurangi makna dari be-

\section{DAFTAR RUJUKAN}

"Pelajaran 01 - Latar Belakang Politik, Sosial, Dan Ekonomi Dunia Perjanjian Baru.” http:// pesta.sabda.org/ppb_pel01

Braga, James. 2005. Cara Menelaah Alkitab, Malang: Gandum Mas.

Carson, D.A. 2018. Kristus dan Kebudayaan Sebuah Kajian Baru. Surabaya: Momentum. rita tersebut. Strategi kedua adalah menggunakan media yang ada dalam budaya. Pada bagian ini, Yesus menyampaikan suatu cerita yang tidak asing bagi masyarakat umum yaitu tentang pelita atau lampu. Perumpamaan tentang pelita menjadi sebuah cerita yang terkait dengan media yang ada dalam budaya setempat. Strategi yang Yesus gunakan membuat berita mudah dimengerti oleh semua kalangan.

Strategi ketiga yang digunakan oleh Yesus adalah memberdayakan potensi yang ada. Dalam Markus 4:1-20 Yesus berbicara tentang benih yang ditabur dan tanpa campur tangan manusia benih itu bertumbuh dengan sendirinya, hal ini menjelaskan tentang kedaulatan Allah dalam segala kehidupan di dunia ini. Pendekatan yang Yesus pada masyarakat ada di sekitar danau Galilea adalah dengan menggunakan ilustrasi tentang benih, dan hampir semua mengerti tentang hal itu. Tampaknya Yesus melihat berbagai potensi yang ada di sekitar masyarakat yang dapat digunakan-Nya untuk memberitakan Injil.

Strategi keempat yang dilakukan Yesus adalah menciptakan terobosan. Dalam pelayanan Yesus, Ia memberikan pemahaman dan pengertian dalam ilustrasi-ilustrasinya tentang seorang penabur; ilustrasi tentang pelita; ilustrasi tentang benih dan; ilustrasi tentang biji sesawi dan masing-masing ilustrasi memiliki nilai-nilai kebenaran yang hendak disampaikan-Nya tanpa mengurangi maknanya. Penggunaan strategi ini dianggap relevan dalam menyampaikan Injil dalam lintas budaya karena cerita yang digunakan adalah informasi yang dikenal oleh semua kalangan sosial.

Dekker, John. 2002. Pelayanan Lintas Budaya, Surabaya: STII.

Drane, John. 2001. Memahami Perjanjian Baru. Jakarta: BPK Gunung Mulia.

Hakh, Samuel Benyamin. 2008. Pemberitaan tentang Yesus Menurut Injil Sinoptik. Bandung: Jurnal Info Media. 
Harming. 2017. "Metode Penginjilan Yesus dalam Injil Yohanes 4:1-42." Jurnal Evangelikal: Jurnal Teologi Injili dan Pembinaan Warga Jemaat, 1 (1): 162-169.

Nainggolan, B.D. 2013. "Penafsiran Kisah Para Rasul 1:8 dan Implementasi Misi Pemberitaan Injil Lintas Budaya.” Jurnal Koinonia, 6 (2).

Nainggolan, Bartholomeus Diaz. 2013. "Penafsiran Kisah Para Rasul 1:8 dan Implementasi Misi Pemberitaan Injil Lintas Budaya," Jurnal Koinonia, 6 (2).

Timo, E. I. N. 2013. Gereja Lintas Agama Pemikiran-Pemikiran bagi Pembaharuan Kekristenan di Asia. Salatiga: Satya Widya University Press.

O’dea, Thomas. 1996. Sosiologi Agama. Jakarta: Raja Grafindo.

Packer, J.I. 2014. Penginjilan dan Kedaulatan Allah. Surabaya: Momentum.

Riniwati, R. 2016. "Iman Kristen Dalam Pergaulan Lintas Agama." Jurnal Simpson: Jurnal Teologi dan Pendidikan Agama Kristen, 1 (1): 21-36

Samarenna, Desti. 2017. "Berteologi Dalam Konteks Indonesia Modern." Jurnal Evangelikal: Jurnal Teologi Injili dan Pembinaan Warga Jemaat, 1 (1).

Siswanto, K. 2017. "Perjumpaan Injil dan Tradisi Jawa Timuran dalam Pelayanan Misi Kon- tekstual." Jurnal Evangelikal: Jurnal Teologi Injili dan Pembinaan Warga Jemaat, 1 (1): 61-66.

Sproul, R.C. 2010.Mengenal Alkitab Seri Teologi Sistematika. Malang: Literatur SAAT.

Sutanto, H. 2001. Hermeneutik: Prinsip dan Metode Penafsiran Alkitab. Malang: Literatur SAAT.

Tafsiran Alkitab Wycliffe, Yayasan Lembaga SABDA (YLSA) (OLB versi Indonesia) Versi 4.30, 6 September 2013.

Tafsiran Matthew Henry, Yayasan Lembaga SABDA (YLSA) (OLB versi Indonesia) Versi 1.4.1, Mei 2018.

Tafsiran Wycliffe, Yayasan Lembaga SABDA Versi 1.2.0, 2016.

Tolbert, John T. 2016. Practical Evangelism. Malang: Gandum Mas.

Wellem, F.D. 1997. Kamus Sejarah Gereja. Jakarta: BPK Gunung Mulia.

Wijaya, P. A., \& Darmawan, I. P.A. 2016. "Pembekalan Pendekatan Penginjilan Di GKII Gerizim Nusa Dua". Prosiding Seminar Nasional PAK dan call for papers (pp. 52-57). Ungaran: Sekolah Tinggi Teologi Simpson.

Yayasan Lembaga SABDA (YLSA) (OLB versi Indonesia) Versi 4.30, 6 September 2013.

Yewangoe, Andreas. 2009. Tidak Ada Penumpang Gelap. Jakarta: BPK Gunung Mulia. 